○松本智尋・山本英明・荒井 孝 恵田成幸・池井勝美・橋本 宏

〔目的〕腎疾患などの臨床評価に用いられる活性型レ ニン濃度，レニン活性值の有用性および相関を検討する ため,レニン IRMA パスツールキット,レニンリアビー ズを用いて比較をしたままた，各種疾患における臨床的 評価も併せて行った。

[結果] 新しく用いたパスツールキットの測定精度は, 再現性, 添加回収率試験, 希釈試験などにおいて良好な 結果が得られた: ANP，アルドステロンなど他検查結果 との比較においては, 両者とも逆相関, 正相関と同様な 変化を示し，また互いの関係は高い相関を示した。しか し，レニン活性值側に数検体解離するものが見うけられ， 今後詳細な検討を加える必要があるものと思われた。

\section{5. 全身用骨塩定量装置の基礎的評価と問題点}

山梨医科大学医学部附属病院放射線部

○木村淳一郎・藤田克也・舘田良仁 萩原充人・新井誉夫・佐野芳知 中村 修

〔目的〕ホロジック社製全身用骨塩定量装置 QDR$1000 \mathrm{~W}$ の基礎評価と問題点について，検討を加えた。

[結果] 日内変動率は, $\mathrm{SD}=0.0048, \mathrm{CV}=0.494 \%$, 月差変動率は, $\mathrm{SD}=0.0024, \mathrm{CV}=0.239 \%$ となり, 装置 自体の再現性はよい。

オペレータによるデータ解析時の鿁差は，技師10名で は，全身骨密度は，ほとんどゼロで，部位別にみても 0.1 〜 $2.8 \%$ とバラツキは少ない.

被曝線量は，皮膚面で，252.8 nC/ $\mathrm{kg}(0.98 \mathrm{mR})$ であ った.

\section{座長集約}

演題41は，千葉県内の核医学検直の推移を10年前のア ンケート調査と比較したものであるが，日本人の死しの 3 大要因である嵒・脳硬塞・心筋硬塞を中心とした

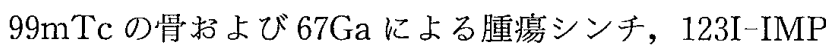
による脳血流, そして 201T1による心筋シンチが主流と なる結果となった。

演題42は, 前演題の結果のように, 現在の検査項目の 中でも使用度の高い検查で，そのために生じるリスクを 第 3 者を中心としての被曝線量当量と癌への危険率を推 定した報告で放射線による環境問題の上でも重要であり， 安易な検査ずけ医療にも警鐘となろう。

演題43は，免疫抑制剤として使用されているシクロス ポリンの測定キットの有用性についてであるが，本剂は 移植臟器との免疫抑制効果が非常に優れているが, 腎障
害などの強い副作用が問題となり，的確な投与で一定の 血中濃度を保つことが重要で, 他の薬剤との相互作用に よる濃度変化も考慮しなければならず，血中濃度測定は 重大な意味をもつ.

演題44 従来のレニン測定法では, 通常活性型レニン と不活性型レニンの総量を測定し, 演者らが使用したヒ トレニンに対するモノクロナール抗体を用いたレニン IRMA 法は，活性型レニンのみを測定する直接測定法で あるため酵素反応にかかわる種々の阻害因子の影響を受 けにくいはずである，操作面では，演者も述べているが 抗体磁気試薬の覺汼の注意が必要で，血漿の分離にあた っては低温 (氷冷) で素早く行うことが重要である.

演題45 骨塩定量法には，多くの方法があり，それぞ れ異なる意義を持ち，どの方法でどの骨を測定すること がよいか定まった見解がないようで，全身用骨塩定量装 置の発表も未だ数少なく，全身の骨塩測定による臨床的 評洒も自ずと少ない。骨塩定量に扔いて患者のポジショ ニングの再現性がどの装置，どの方法においても問題の ように思われた。

\section{管理・情報}

座長 福井利治（防衛医科大学校病院）

\section{6. バイプレーン DCI における被曝線量の検討}

埼玉県立小览医療センター放射線部

$\bigcirc$ 増田和浩・鍋倉良三・松田幸広

山口明・橋本 宏

Digital Cardiac Imaging（DCI）を使用したシネ撮影 とDSA について，その被儤線量を TLD 素子を用いて測 定した.バイプレーンシネ撮影と DCI の被曝線量は，心

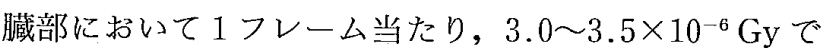
あった. 一方, 脳血管撮影においては中心部でバイプレ ーン 1 曝射当たり AOT で $0.6 \times 10^{-6} \mathrm{~Gy}$ ，DCI を用いた DSA に扎ては, $0.2 \times 10^{-6} \mathrm{~Gy}$ であった. DCI を使用す ることで，特に線量が増加することはなく，従来法と同 等かそれ以下の線量で鮮明な画像を得ることができ, 被 懪線量の面からは，現在のところ大きな問題はないもの と思われ，フィルム化と共に血管撮影の今後の動向を示 唆してゆく装置であるものと考えられた。

47. 䀢療法改正と実施への対応についてーX線撮影室に おけるマニュアルの作成一

群馬中央総合病院

○岸 俊夫・新井敏子

群馬県立がんセンター東毛病院 星野欽一郎

群馬大学医学部付属病院 宮澤康志

群馬県庁衛生環境部 川崎英弘 